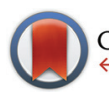

CrossMark \&click for updates

Cite this: Dalton Trans., 2015, 44, 14341

Received 14th May 2015,

Accepted 26th June 2015

DOI: $10.1039 / c 5 d t 01806 d$

www.rsc.org/dalton

\section{Syntheses, structural characterisation and electronic structures of some simple acyclic amino carbene complexes $\uparrow+$}

\author{
Samantha G. Eaves, ${ }^{\text {a, b }}$ Dmitry S. Yufit, ${ }^{a}$ Brian W. Skelton, ${ }^{c}$ Judith A. K. Howard ${ }^{a}$ and \\ Paul J. Low ${ }^{\star a, b}$
}

\section{Introduction}

Heteroatom-stabilised carbene ligands have played an important role in the development of organometallic chemistry. Since the seminal work of Fischer identifying the earliest examples of this class of compound, extensive studies of the synthesis and properties of complexes bearing carbene ligands have seen carbenes rise to such prominence as supporting ligands that they now rival phosphines as the ubiquitous 2-electron $\sigma$-donor ligand. Indeed, many of the spectacular advances in the area of metal complexes of carbenes are correlated with the pioneering efforts that have made stable carbenes available as reagents. ${ }^{1}$

Stable (i.e. isolable) carbenes have been known since 1988, when the Bertrand group reported the phosphino(silyl)carbene $\left({ }^{\mathrm{i}} \mathrm{Pr}_{2} \mathrm{~N}\right)_{2} \mathrm{PCSiMe}_{3} .{ }^{2}$ Since then, phosphino(phosphonio)-, ${ }^{3}$ phosphino(amino)-, ${ }^{4}$ acyclic diamino carbenes, ${ }^{5}$ dicarbene- ${ }^{6}$ mono-phosphino- ${ }^{7}$ mono-amino- ${ }^{8}$ and a wide range of cyclic heteroatom-stabilised carbenes, including of course N-heterocyclic carbenes (NHCs), ${ }^{9}$ have been explored. However, whilst cyclic heteroatom-stabilised carbenes have proven to be ligands of wide applicability, ${ }^{10}$ isolated acyclic carbenes have found less use in the preparation of metal complexes, ${ }^{11}$

\footnotetext{
${ }^{a}$ Department of Chemistry, Durham University, South Rd, Durham, DH13LE, UK. E-mail:paul.low@uwa.edu.au

${ }^{b}$ School of Chemistry and Biochemistry, University of Western Australia, 35 Stirling Highway, Crawley, WA, 6009, Australia

${ }^{c}$ Centre for Microscopy, Characterisation and Analysis, University of Western

Australia, Crawley 6009, WA, Australia

$\dagger$ Dedicated to the memory of Professor Kenneth Wade, FRS, an inspirational teacher, mentor, colleague and friend.

¥CCDC 1063656-1063659. For crystallographic data in CIF or other electronic format see DOI: 10.1039/c5dt01806d
}

although it should be noted that these are accessible through modular template synthetic routes, and have given rise to a number of useful catalysts. ${ }^{12}$ In the case of phosphoranyl carbenes, the relatively poor coordinating ability has been attributed to the wide carbene bond angle associated with the greater stability of the triplet form and the consequent significant reorganisation energy cost of complexation in addition to the higher carbene reactivity. ${ }^{13}$

Relatively wide carbene angles are also observed in acyclic mono- and di-amino carbenes such as ${ }^{t} \mathrm{BuC}=\mathrm{N}\left({ }^{\mathrm{i}} \operatorname{Pr}\right)_{2}\left(120.50(12)^{\circ}\right)^{8 a}$ and $\left({ }^{\mathrm{i}} \operatorname{Pr}\right)_{2} \mathrm{NCN}\left({ }^{\mathrm{i}} \mathrm{Pr}\right)_{2}\left(121.0(5)^{\circ}\right),{ }^{14}$ which can be attributed to the steric bulk of the groups necessary to allow isolation of the carbene. These angles contrast the much narrower angles calculated for the smaller parent singlet amino carbene $\mathrm{HCNH}_{2}\left(105.3^{\circ}\right)$ but are closer to the structures of the corresponding triplet $\left(124.1^{\circ}\right) .{ }^{13 b}$ Whilst metal complexes of these bulky acyclic amino carbenes are known, ${ }^{8,13}$ the wide carbene angle decreases the $\sigma$-donor properties of the carbene, and steric factors can also destabilise the resulting complexes. ${ }^{10}$ The constrained geometries in NHCs such as the prototypical Arduengo system, 1,3-diadamantyl-imidazol-2-ylidene $\left(102.2(2)^{\circ}\right),{ }^{15}$ 1,3-dimesitylimidazol-2-ylidene $\left(101.4(2)^{\circ}\right)^{16}$ and the saturated analogue 1,3 -dimesitylimidazolin-2-ylidene $\left(104.7(3)^{\circ}\right)^{16}$ are much closer to the singlet structure of the parent acyclic amino carbene. The propensity of these ligands to form metal complexes is perfectly well established. ${ }^{10}$

In contrast to the coordination reactions of isolated heteroatom-stabilised carbenes with metal complexes, the original Fischer synthesis of alkyloxy-stabilised carbenes involved nucleophilic attack of an alkyl group on a metal-bound carbonyl ligand to given an anionic acyl fragment, and subsequent alkylation. ${ }^{17}$ As a consequence of the electrophilic nature of the carbene carbon, these alkyloxy carbenes are readily 
converted to amino-, thio-, alkyl- or aryl-carbenes providing facile 'on complex' synthetic routes to a wide range of complexes featuring heteroatom-stabilised carbene ligands. ${ }^{18}$ The addition of nucleophiles such as alcohols, thiols or amines to the $\alpha$-carbon of transition metal vinylidene or allenylidene complexes also affords Fischer-type (heteroatom-stabilised) carbene compounds. ${ }^{19,20}$

Here we describe the facile addition of ammonia to the $\alpha$-carbon of the parent vinylidene ligand in complexes $\left[\mathrm{M}\left(=\mathrm{C}=\mathrm{CH}_{2}\right)(\mathrm{PP}) \mathrm{Cp}^{\prime}\right]\left[\mathrm{PF}_{6}\right]\left(\mathrm{M}=\mathrm{Fe}, \mathrm{PP}=\right.$ dppe, $\mathrm{Cp}^{\prime}=\mathrm{Cp} ; \mathrm{M}=\mathrm{Ru}$, $\mathrm{PP}=$ dppe, $\mathrm{Cp}^{\prime}=\mathrm{Cp} ; \mathrm{M}=\mathrm{Ru}, \mathrm{PP}=\left(\mathrm{PPh}_{3}\right)_{2}, \mathrm{Cp}^{\prime}=\mathrm{Cp} ; \mathrm{M}=\mathrm{Ru}$, $\left.\mathrm{PP}=\mathrm{dppe}, \mathrm{Cp}^{\prime}=\mathrm{Cp}^{*}\right)$ to give rare examples of complexes bearing the simple, sterically unencumbered methyl(amino) carbene ligand, $\left[\mathrm{M}\left\{\mathrm{C}(\mathrm{Me}) \mathrm{NH}_{2}\right\}(\mathrm{PP}) \mathrm{Cp}^{\prime}\right] \mathrm{PF}_{6}$. These complexes have been spectroscopically and crystallographically characterised, and their geometric and electronic structures, together with those of the free ligand, explored with additional insight from density functional theory based calculations.

\section{Results and discussion}

\section{Synthesis and characterisation}

The preparation of vinylidene complexes from rearrangement reactions of terminal alkynes within the coordination sphere of metal complexes is very well established. ${ }^{19,21}$ For example, in the case of half-sandwich complexes $\operatorname{MCl}\left(\mathrm{L}_{2}\right) \mathrm{Cp}^{\prime}(\mathrm{L}=$ phosphine or $\mathrm{L}_{2}=$ chelating bis(phosphine), $\mathrm{Cp}^{\prime}=\mathrm{Cp}, \mathrm{Cp}^{*}$ etc.), such reactions with $\mathrm{HC} \equiv \mathrm{CR}$ are typically performed in polar solvents such as methanol at reflux and in the presence of a salt, often $\mathrm{NH}_{4} \mathrm{PF}_{6}$, to enhance the ionisation of the $\mathrm{M}-\mathrm{Cl}$ bond and provide a large anion to assist isolation of the product cation $\left[\mathrm{M}\{=\mathrm{C}=\mathrm{C}(\mathrm{H}) \mathrm{R}\}\left(\mathrm{L}_{2}\right) \mathrm{Cp}^{\prime}\right]^{+}$(Scheme 1). ${ }^{19,22,23}$ Whilst the ancillary ligands and the $\mathrm{R}$ group provide a degree of steric protection for the electrophilic $\alpha$-carbon, prolonged reaction leads to the conversion of the vinylidene to the corresponding methoxy carbene $\left[\mathrm{M}\left\{=\mathrm{C}(\mathrm{OMe}) \mathrm{CH}_{2} \mathrm{R}\right\}\left(\mathrm{L}_{2}\right) \mathrm{Cp}^{\prime}\right]^{+} .{ }^{24}$ In the case of the formation of terminal vinylidene complexes $\left[\mathrm{M}\left(=\mathrm{C}=\mathrm{CH}_{2}\right)\right.$ $\left.\left(\mathrm{L}_{2}\right) \mathrm{Cp}^{*}\right]^{+}$from $\mathrm{MCl}\left(\mathrm{L}_{2}\right) \mathrm{Cp}^{*}, \mathrm{HC} \equiv \mathrm{CSiMe}_{3}$ and $\mathrm{NH}_{4} \mathrm{PF}_{6}$, methanol remains a suitable solvent; ${ }^{25}$ however, the less sterically restricted $\mathrm{Cp}$ derivatives require the use of either a bulkier alkyl alcohol (such as $\left.{ }^{t} \mathrm{BuOH}\right)^{26}$ or prolonged reaction time in a non-nucleophilic solvent, such as $\mathrm{CH}_{2} \mathrm{Cl}_{2} \cdot{ }^{27}$

Interestingly, the prolonged $(15 \mathrm{~h})$ reaction of the $\eta^{5}$ indenyl complex $\mathrm{RuCl}(\mathrm{dppm})\left(\eta^{5}-\mathrm{C}_{9} \mathrm{H}_{7}\right)$ with $\mathrm{HC} \equiv \mathrm{CSiMe}_{3}$ and $\mathrm{NH}_{4} \mathrm{PF}_{6}$ in $\mathrm{CH}_{2} \mathrm{Cl}_{2}$ at elevated temperatures $\left(90^{\circ} \mathrm{C}\right)$ in a sealed tube gave a methyl(amino) carbene complex, formulated as $\left[\mathrm{Ru}\left\{=\mathrm{C}(\mathrm{Me}) \mathrm{NH}_{2}\right\}(\mathrm{dppm})\left(\eta^{5}-\mathrm{C}_{9} \mathrm{H}_{7}\right)\right] \mathrm{PF}_{6} \quad$ (Scheme 2$) .{ }^{28}$ To the best of our knowledge, this is the only example of a complex bearing the parent alkyl(amino) carbene fragment, and whilst spectroscopically well characterised ${ }^{28}$ no crystallographic data are available through which to examine the effect of coordination on the key $\mathrm{N}-\mathrm{C}-\mathrm{C}_{\mathrm{Me}}$ bond angle.

Having observed similar products formed as minor by-products in preparations of vinylidene complexes $\left[\mathrm{M}\left(=\mathrm{C}=\mathrm{CH}_{2}\right)\left(\mathrm{L}_{2}\right)\right.$ $\left.\mathrm{Cp}^{\prime}\right] \mathrm{PF}_{6}$ from $\mathrm{MCl}\left(\mathrm{L}_{2}\right) \mathrm{Cp}^{\prime}, \mathrm{HC} \equiv \mathrm{CSiMe}_{3}$ and $\mathrm{NH}_{4} \mathrm{PF}_{6}$, we
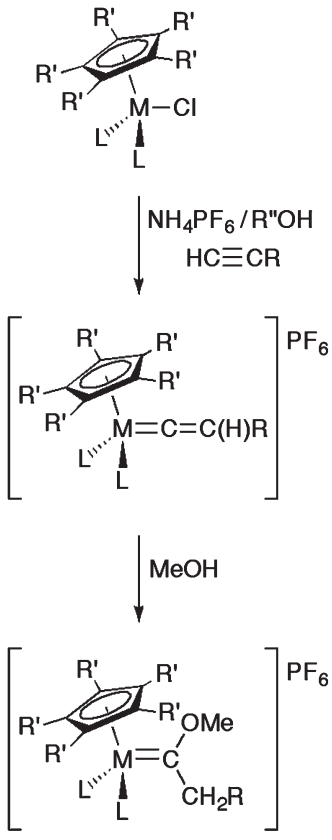

Scheme 1 Representative syntheses of vinylidenes and methoxy carbenes from half-sandwich $\mathrm{MCl}\left(\mathrm{L}_{2}\right) \mathrm{Cp}^{\prime}$ precursors.

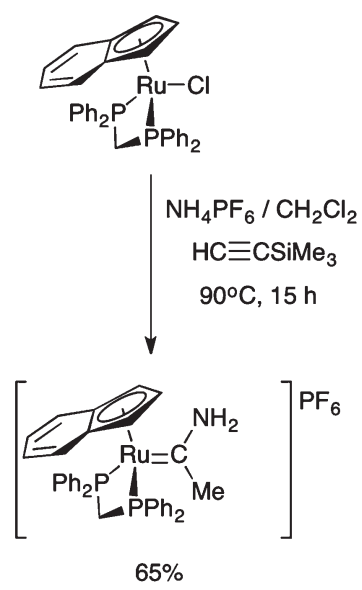

Scheme 2 The prolonged reaction of $\mathrm{RuCl}(\mathrm{dppe})\left(\eta^{5}-\mathrm{C}_{9} \mathrm{H}_{7}\right)$ with $\mathrm{HC} \equiv \mathrm{CSiMe}_{3}$ and $\mathrm{NH}_{4} \mathrm{PF}_{6}{ }^{28}$

pursued a more direct synthesis to complexes containing this simple acyclic amino carbene. The reactions of the halfsandwich complexes $\left[\mathrm{Fe}\left(=\mathrm{C}=\mathrm{CH}_{2}\right)(\mathrm{dppe}) \mathrm{Cp}\right] \mathrm{PF}_{6}\left([\mathbf{1} \mathbf{a}] \mathrm{PF}_{6}\right),[\mathrm{Ru}-$ $\left.\left(=\mathrm{C}=\mathrm{CH}_{2}\right)(\mathrm{dppe}) \mathrm{Cp}\right] \mathrm{PF}_{6}\left([\mathbf{1 b}] \mathrm{PF}_{6}\right),\left[\mathrm{Ru}\left(=\mathrm{C}=\mathrm{CH}_{2}\right)\left(\mathrm{PPh}_{3}\right)_{2} \mathrm{Cp}\right]-$ $\mathrm{PF}_{6}\left([\mathbf{1 c}] \mathrm{PF}_{6}\right)$ and $\left[\mathrm{Ru}\left(=\mathrm{C}=\mathrm{CH}_{2}\right)(\mathrm{dppe}) \mathrm{Cp}^{*}\right] \mathrm{PF}_{6}\left([\mathbf{1 d}] \mathrm{PF}_{6}\right)$ with $\mathrm{NH}_{3}$ proceeded smoothly at room temperature in $\mathrm{CH}_{2} \mathrm{Cl}_{2}$ to give the amino carbene complexes $\left[\mathrm{Fe}\left\{\mathrm{C}(\mathrm{Me}) \mathrm{NH}_{2}\right\}(\mathrm{dppe}) \mathrm{Cp}\right]$ $\mathrm{PF}_{6} \quad\left([2 \mathbf{2 a}] \mathrm{PF}_{6}\right), \quad\left[\mathrm{Ru}\left\{\mathrm{C}(\mathrm{Me}) \mathrm{NH}_{2}\right\}(\mathrm{dppe}) \mathrm{Cp}\right] \mathrm{PF}_{6} \quad\left([2 \mathbf{b}] \mathrm{PF}_{6}\right), \quad[\mathrm{Ru}-$ $\left.\left\{\mathrm{C}(\mathrm{Me}) \mathrm{NH}_{2}\right\}\left(\mathrm{PPh}_{3}\right)_{2} \mathrm{Cp}\right] \mathrm{PF}_{6} \quad\left([2 \mathrm{c}] \mathrm{PF}_{6}\right)$ and $\quad\left[\mathrm{Ru}\left\{\mathrm{C}(\mathrm{Me}) \mathrm{NH}_{2}\right\}-\right.$ (dppe)Cp* $] \mathrm{PF}_{6}\left([2 \mathrm{~d}] \mathrm{PF}_{6}\right.$ ) in $77-94 \%$ isolated yields (Scheme 3). Whilst reactions were complete in 1-4 $\mathrm{h}$ for the $\mathrm{Cp}$ complexes, in the case of $[\mathbf{2 d}] \mathrm{PF}_{6}$, overnight reaction was required to 


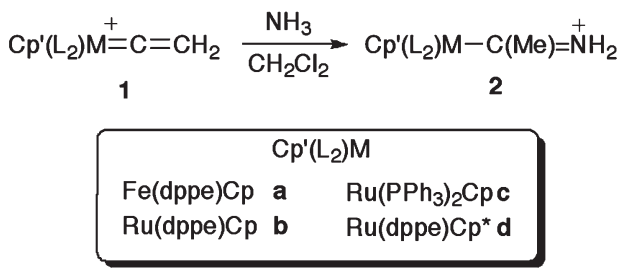

Scheme 3 The reaction of $[1 \mathrm{a}-\mathrm{d}]^{+}$with $\mathrm{NH}_{3}$ to afford $[2 \mathrm{a}-\mathrm{d}]^{+}$.

complete the conversion, no doubt a consequence of the additional steric protection afforded to the vinylidene $\alpha$-carbon by the $\mathrm{Cp}^{*}$ ligand.

The complexes were readily characterised by the usual spectroscopic methods, and single crystal X-ray diffraction studies. In NMR spectra (Table 1), triplets (unresolved in the case of $\left.[2 \mathrm{c}]^{+}\right)$in the ${ }^{13} \mathrm{C}\left\{{ }^{1} \mathrm{H}\right\}$ NMR spectra between $253-275 \mathrm{ppm}$ confirmed the carbene-nature of the $\alpha$-carbon, whilst two unresolved low-field doublets in the ${ }^{1} \mathrm{H}$ NMR spectra, each integrating to a single proton, indicated the restricted rotation about the $\mathrm{C}(\alpha)-\mathrm{N}$ bond, supporting a $\mathrm{C}=\mathrm{N}^{(+)} \mathrm{H}_{2}$ valence description. The iminium description was further enhanced by the observation of the $\mathrm{Cp}$ resonances for $[\mathbf{2 a}-\mathbf{c}] \mathrm{PF}_{6}$ between 4.37-4.80 ppm (cf. FeCl(dppe)Cp 4.76; RuCl(dppe)Cp 4.55; ${ }^{29}$ $\operatorname{RuCl}\left(\mathrm{PPh}_{3}\right)_{2} \mathrm{Cp} 5.99 ;^{23}\left[\mathbf{1 a}^{2} \mathrm{PF}_{6} \quad 5.25 ;^{26}[\mathbf{1 b}] \mathrm{PF}_{6} \quad 5.37 ;^{26}[\mathbf{1 c}] \mathrm{PF}_{6}\right.$ $5.09^{27} \mathrm{ppm}$ ). A singlet between $1.60-2.90 \mathrm{ppm}$ (integrating to $3 H$ ) was assigned to the methyl group of the carbene ligand. In the positive ion electrospray $(\mathrm{ES}(+))$ mass spectra, ions corresponding to the cation were clearly observed. In the IR spectra, bands in the range $1600-1650 \mathrm{~cm}^{-1}$ were assigned to $\delta\left(\mathrm{NH}_{2}\right)$ with the assistance of DFT based molecular models (vide infra).

\section{Molecular structures}

Single crystal X-ray diffraction studies were carried out on $[\mathbf{2 a}-\mathbf{d}] \mathrm{PF}_{6}$ to explore the amino carbene ligand geometry and metal-carbene bond lengths. A representative plot of the cation of $[2 \mathbf{a}]^{+}$is shown in Fig. 1, and selected bond lengths and angles are summarised in Table 2. The $\mathrm{Ru}-\mathrm{C}(1)$ bond lengths fall at the longer end of the range spanned by the crystallographically characterised examples of methyl(methoxy) carbene complexes: $\left[\mathrm{Ru}\left\{=\mathrm{C}(\mathrm{OMe}) \mathrm{Me} \mathrm{L}_{n}\right]^{+}\left(\mathrm{RuL}_{n}=\operatorname{RuCl}\{\mathrm{P}(\mathrm{CH}=\right.\right.$ $\left.\left.\mathrm{CH}_{2}\right) \mathrm{Ph}_{2}\right\}\left(\eta^{6}-\mathrm{C}_{6} \mathrm{H}_{2} \mathrm{Me}_{4}\right) \quad 1.963(7) \quad \AA^{30} ;{ }^{30} \quad \mathrm{Ru}\left\{\mathrm{P}\left(\mathrm{CH}=\mathrm{CH}_{2}\right)_{2} \mathrm{Ph}\right\}_{2}-$ $\left(\eta^{5}-\mathrm{C}_{5} \mathrm{H}_{4} \mathrm{Me}\right) \quad 1.921(10) \quad \AA{ }^{31} \quad \operatorname{RuCl}\left\{\mathrm{P}\left(\mathrm{CH}=\mathrm{CH}_{2}\right) \mathrm{Ph}_{2}\right\}\left(\eta^{6}-\mathrm{C}_{6} \mathrm{Me}_{6}\right)$

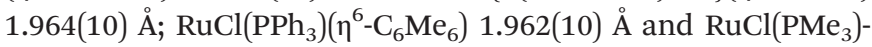
$\left(\eta^{6}-\mathrm{C}_{6} \mathrm{Me}_{6}\right) 2.015(8) \AA^{32}$ The $\mathrm{M}-\mathrm{C}(1), \mathrm{C}(1)-\mathrm{N}(1)$ and $\mathrm{C}(1)-\mathrm{C}(2)$

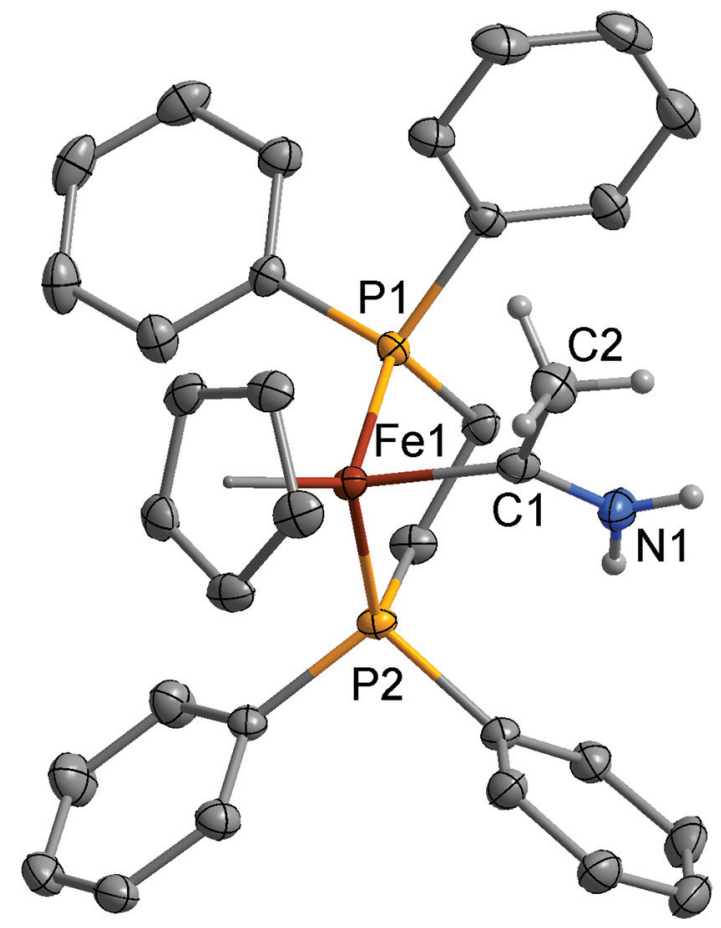

Fig. 1 Structure of one of the cations of $[2 \mathrm{a}]^{+}$with selected hydrogen atoms omitted for clarity. Ellipsoids have been drawn at the $50 \%$ probability level.

distances are consistent with a predominant description in terms of a strongly $\mathrm{N}$-stabilised carbene with a significant degree of $\mathrm{C}=\mathrm{NH}_{2}$ double bond character and a $\mathrm{M}-\mathrm{C}$ single bond. There is little change in the carbene angles across the series $[\mathbf{2 a - d}]^{+}$, suggesting $\pi$-interaction between the metal and carbene is not significant. The relatively precisely determined $\mathrm{M}-\mathrm{P}$ bond lengths are sensitive to $\mathrm{M}-\mathrm{P}$ back-bonding effects, and can be used as a proxy measure of the relative electron density at the metal centre. ${ }^{33}$ Here, the Fe-P and $\mathrm{Ru}-\mathrm{P}$ bond distances in $[\mathbf{2 a}]^{+},[\mathbf{2 b}]^{+},[\mathbf{2 c}]^{+}$and $[\mathbf{2 d}]^{+}$compare with those of the vinylidene cations $\left[\mathrm{Fe}\left(=\mathrm{C}=\mathrm{CH}_{2}\right)(\mathrm{dppe}) \mathrm{Cp}^{*}\right]^{+}$(2.2219(15), 2.2185(16) $\mathrm{A}),{ }^{34}\left[\mathrm{Ru}\left(=\mathrm{C}=\mathrm{CH}_{2}\right)\left(\mathrm{PPh}_{3}\right)_{2} \mathrm{Cp}^{*}\right]^{+}$(2.362(2), 2.355(2) $\AA),{ }^{35}\left[\mathrm{Ru}\left(=\mathrm{C}=\mathrm{CH}_{2}\right)(\mathrm{dppe}) \mathrm{Cp}^{*}\right]^{+}\left([2 \mathrm{~d}]^{+} 2.320(3), 2.317(3) ; 2.318(3)\right.$, $2.308(3) \AA)^{25}$ and the methyl-(methoxy) carbene complex [Ru$\left.\left\{\mathrm{C}(\mathrm{OMe}) \mathrm{CH}_{2} \mathrm{CO}_{2} \mathrm{Me}\right\}(\mathrm{dppe}) \mathrm{Cp}\right]^{+}(2.2890(9), 2.3043(10) \AA) .{ }^{36}$ The shorter $\mathrm{M}-\mathrm{P}$ bond lengths in the amino carbene complexes indicates more electron-density at the metal than in the vinylidenes, which is consistent with the poorer $\pi$-accepting character of the Fischer-type carbene.

Table 1 Selected spectroscopic data for complexes $[1 \mathrm{a}] \mathrm{PF}_{6},{ }^{26}[\mathbf{1 b}] \mathrm{PF}_{6},{ }^{26,27}[1 \mathrm{c}] \mathrm{PF}_{6},{ }^{27}[1 \mathrm{~d}] \mathrm{PF}_{6},{ }^{25}$ and [2a-d]PF

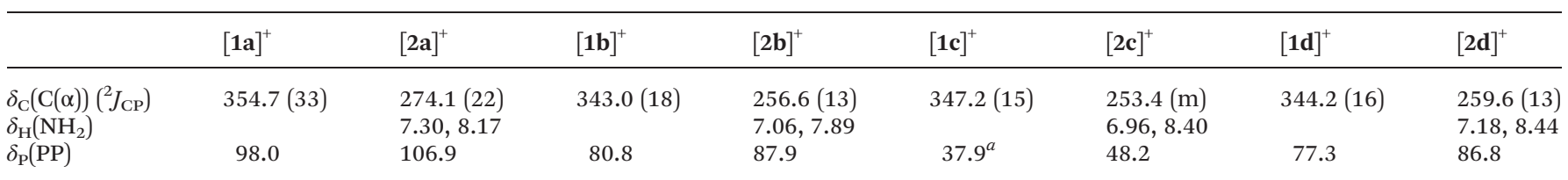

${ }^{a}$ Value as determined here. 
Table 2 Selected bond lengths $(\AA \AA)$, and bond angles $\left(^{\circ}\right)$ for $[2 a-d] P F_{6}$, together with data from ${ }^{t} \mathrm{BuC}=\mathrm{N}\left({ }^{i} \mathrm{Pr}\right)_{2}{ }^{8 a}$ and the DFT $(\mathrm{B} 3 \mathrm{LYP} / \mathrm{LANL} 2 \mathrm{DZ}$ $\left.(\mathrm{Ru}, \mathrm{Fe}), 6-31 \mathrm{G} * * / \mathrm{COSMO}\left(\mathrm{CH}_{2} \mathrm{Cl}_{2}\right)\right)$ optimised geometries of $[2 \mathrm{a}]^{+}$and $[2 \mathrm{~b}]^{+}$and gas phase $\left(\mathrm{B} 3 \mathrm{LYP} / 6-31 \mathrm{G}^{\star *}\right)$ geometries of the free singlet carbenes $\mathrm{MeC}=\mathrm{NH}_{2}$ and ${ }^{\mathrm{t}} \mathrm{BuC}=\mathrm{N}\left({ }^{\mathrm{i}} \mathrm{Pr}\right)_{2}$ (italics)

\begin{tabular}{lllllll}
\hline & $\mathrm{MeC}=\mathrm{NH}_{2}$ & ${ }^{t} \mathrm{BuC}=\mathrm{N}\left({ }^{\mathrm{i}} \mathrm{Pr}\right)_{2}$ & {$[\mathbf{2 a}] \mathrm{PF}_{6}$} & {$[2 \mathbf{b}] \mathrm{PF}_{6}$} & {$[2 \mathbf{c}] \mathrm{PF}_{6}$} & {$[2 \mathbf{2 d}] \mathrm{PF}_{6}$} \\
\hline $\mathrm{M}-\mathrm{P} 1$ & & $2.1756(4), 2.1829(4) 2.1860$ & $2.2657(7), 2.2733(7) 2.3740$ & $2.326(1)$ & $2.2910(7)$ \\
$\mathrm{M}-\mathrm{P} 2$ & & & $2.2032(4), 2.1860(4) 2.1829$ & $2.2566(7), 2.2704(7) 2.3356$ & $2.328(1)$ & $2.2819(7)$ \\
M-C1 & & & $1.9272(15), 1.9251(15) 1.9250$ & $2.020(3), 2.021(3) 2.0265$ & $2.014(4)$ & $2.016(3)$ \\
$\mathrm{C} 1-\mathrm{N} 1$ & 1.3266 & $1.2976(17) 1.3214$ & $1.312(2), 1.310(2) 1.3099$ & $1.305(4), 1.307(4) 1.3209$ & $1.309(5)$ & $1.368(4)$ \\
$\mathrm{C} 1-\mathrm{C} 2$ & 1.5071 & $1.5392(18) 1.5452$ & $1.518(2), 1.519(2) 1.5186$ & $1.518(4), 1.515(4) 1.5157$ & $1.506(6)$ & $1.454(6), 1.477(5)^{a}$ \\
N1-C1-C2 & 112.30 & $120.50(12) 122.62$ & $109.4(1), 109.5(1) 109.51$ & $110.0(3), 110.4(2) 111.84$ & $111.9(4)$ & $109.5(4), 108.7(3)^{a}$
\end{tabular}

${ }^{a}$ Methyl group C(2) disordered over two sites.

\section{Density functional modelling}

To explore the electronic structure of these complexes we turned to DFT calculations (B3LYP/LANL2DZ Ru, Fe; 6-31G** all other atoms/COSMO $\left.\left(\mathrm{CH}_{2} \mathrm{Cl}_{2}\right)\right)$ with gas-phase calculations also performed on the free ligand (B3LYP/6-31G**) for comparison. The free carbene $\mathrm{MeC}=\mathrm{NH}_{2}$ has a singlet ground

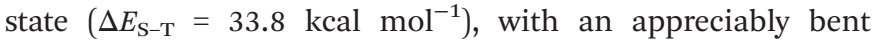
$\left(112.30^{\circ}\right)$ structure, which compares with the corresponding triplet $\left(127.59^{\circ}\right)$. Interestingly, the bulkier analogue ${ }^{t} \mathrm{BuC}=$ $\mathrm{N}\left({ }^{\mathrm{i}} \mathrm{Pr}\right)_{2}$, for which a singlet ground state is also calculated $\left(\Delta E_{\mathrm{S}-\mathrm{T}}=\right.$ $35.8 \mathrm{kcal} \mathrm{mol}^{-1}$ ), demonstrates a significant additional steric influence on the ground state structures in both the singlet $\left(122.62^{\circ}\right)$ and triplet $\left(137.40^{\circ}\right)$ configurations.

The compounds $[\mathbf{2 a}]^{+}$and $[\mathbf{2 b}]^{+}$were chosen as representative examples of the metal complexes of methyl(amino) carbene, allowing exploration of any influence that the $3 \mathrm{~d} v s$. $4 \mathrm{~d}$ metal might play on the electronic structure of the complexes. Key bond lengths and angles from the optimised structures are summarised in Table 2, and the composition of selected frontier orbitals are summarised in Table 3, with supporting plots given in Fig. 2. There is little change between the calculated geometry of the gas-phase carbene $\mathrm{MeC}=\mathrm{NH}_{2}$ and the amino carbene ligand in the complexes. The electronic structures of $[\mathbf{2 a}]^{+}$and $[\mathbf{2} \mathbf{b}]^{+}$are remarkably similar, with the HOMO-2 to LUMO+1 being well described as the metal $d_{z^{2}}$,

Table 3 Energy (eV) and composition (\%) of selected frontier orbital plots of $[2 a]^{+}$and $[2 b]^{+}$

\begin{tabular}{lcrrrrrr}
\hline & Energy & $\mathrm{Fe}$ & $\mathrm{C}(1)$ & $\mathrm{NH}_{2}$ & $\mathrm{Me}$ & dppe & $\mathrm{Cp}$ \\
\hline LUMO+1 & -1.29 & 8 & 27 & 10 & 3 & 51 & 1 \\
LUMO & -1.54 & 37 & 1 & 0 & 0 & 50 & 13 \\
HOMO & -6.10 & 68 & 2 & 3 & 1 & 9 & 16 \\
HOMO-1 & -6.21 & 72 & 2 & 0 & 0 & 9 & 16 \\
HOMO--2 & -6.90 & 84 & 0 & 3 & 0 & 8 & 4 \\
\hline & Energy & $\mathrm{Ru}$ & $\mathrm{C}(1)$ & $\mathrm{NH}_{2}$ & $\mathrm{Me}$ & $\mathrm{dppe}$ & $\mathrm{Cp}$ \\
\hline LUMO+1 & -1.28 & 14 & 27 & 8 & 3 & 40 & 7 \\
LUMO & -1.55 & 28 & 0 & 0 & 0 & 56 & 16 \\
HOMO & -5.97 & 60 & 2 & 2 & 2 & 16 & 19 \\
HOMO-1 & -6.14 & 56 & 4 & 1 & 0 & 12 & 26 \\
HOMO-2 & -6.73 & 78 & 1 & 5 & 0 & 11 & 5
\end{tabular}

$\mathrm{d}_{x^{2}-y^{2}}, \mathrm{~d}_{x y}, \mathrm{~d}_{y z}$ and $\mathrm{d}_{x z}$ admixed with the $\mathrm{N}=\mathrm{C} \pi^{*}$ system. There is no $\pi$-type interaction between the metal and the carbene carbon, the $\mathrm{N}=\mathrm{C} \pi$ bonding combination lying as low as the HOMO-21 $\left([2 \mathbf{a}]^{+}\right)$and HOMO-20 $\left([2 \mathbf{b}]^{+}\right)$. The amino carbene moiety therefore serves as a simple $\sigma$-donor ligand to the metal centre, with the singlet carbene being stabilised exclusively by $\pi$-donation from the $\mathrm{N}$-atom.

\section{Conclusion}

Reactions of the terminal vinylidene complexes $\left[\mathrm{M}\left(=\mathrm{C}=\mathrm{CH}_{2}\right)\right.$ (PP) $\left.\mathrm{Cp}^{\prime}\right] \mathrm{PF}_{6}$ with $\mathrm{NH}_{3}$ provide a convenient entry point to complexes bearing the simple acyclic amino carbene ligand. Structural and electronic structure calculations indicate that the ligand acts as a simple singlet carbene, with good $\sigma$-donor character but little $\mathrm{M}(\mathrm{d})-\mathrm{C}(\mathrm{p}) \pi$-interaction. Gas-phase density functional calculations on the free ligand give a singlet-triplet energy gap of $\Delta E_{\mathrm{S}-\mathrm{T}}=33.8 \mathrm{kcal} \mathrm{mol}^{-1}$, with an appreciably bent $\left(112.30^{\circ}\right)$ structure. The related, more sterically encumbered acyclic amino carbene ${ }^{t} \mathrm{BuC}=\mathrm{N}\left({ }^{\mathrm{i}} \mathrm{Pr}\right)_{2}$ also offers a large singlet-triplet energy gap $\left(\Delta E_{\mathrm{S}-\mathrm{T}}=35.8 \mathrm{kcal} \mathrm{mol}^{-1}\right)$, and a more linear structure $\left(\mathrm{N}-\mathrm{C}-\mathrm{C} 122.62^{\circ}\right)$ demonstrating the steric influence on the ground state structure of the singlet. The difficulties in formation and stability of metal complexes of mono(amino) carbenes therefore seems to be due in no small part to the significant steric bulk of the supporting groups necessary to stabilise the singlet carbene. The formation of these ligands through 'on-complex' synthetic methods therefore appears a more suitable entry point for further explorations.

\section{Experimental}

\section{General conditions}

All reactions were carried out under an atmosphere of dry nitrogen using standard Schlenk techniques. Dichloromethane was dried over $\mathrm{CaH}_{2}$, all other solvents were standard reagent grade and used as received. No special precautions were taken to exclude air or moisture during workup. The compounds $\left[\mathrm{Fe}\left(=\mathrm{C}=\mathrm{CH}_{2}\right)(\right.$ dppe $\left.\left.)\right) \mathrm{Cp}\right] \mathrm{PF}_{6}\left([\mathbf{1} \mathbf{a}] \mathrm{PF}_{6}\right),{ }^{26}\left[\mathrm{Ru}\left(=\mathrm{C}=\mathrm{CH}_{2}\right)(\mathrm{dppe})-\right.$

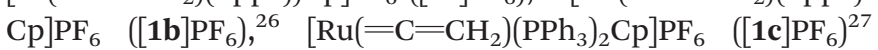



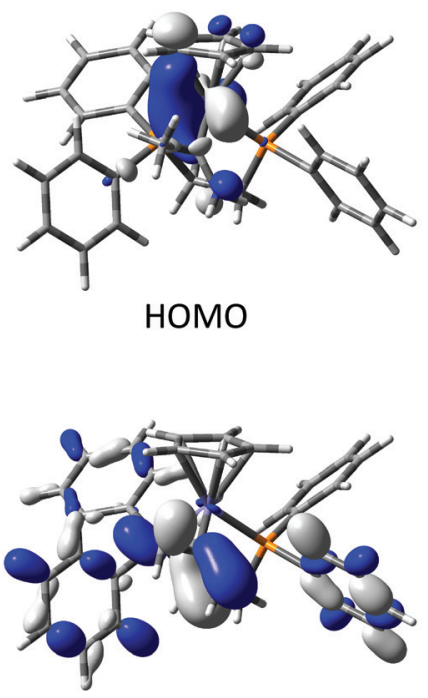

HOMO-21

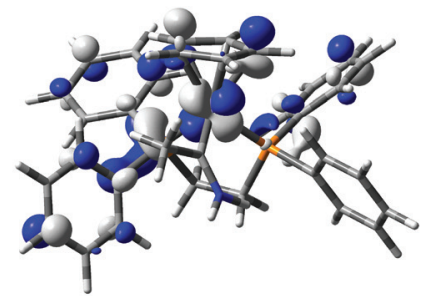

LUMO

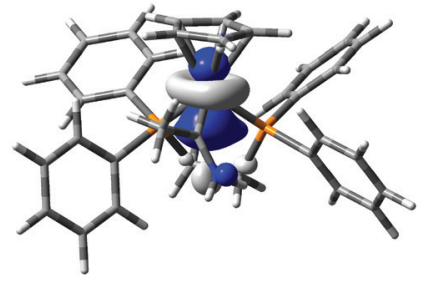

HOMO-2

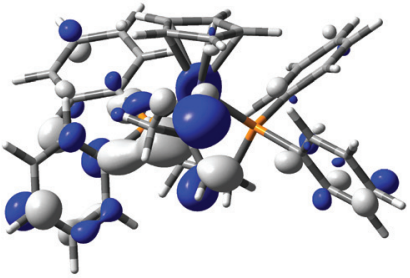

LUMO+1

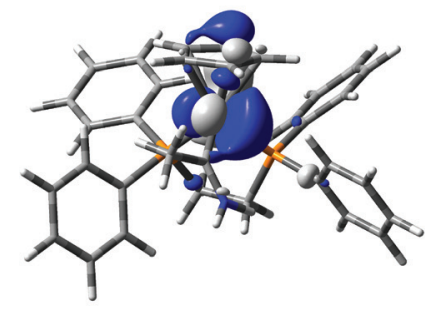

HOMO-1

Fig. 2 Selected frontier orbitals of $[2 \mathrm{a}]^{+}\left(\right.$contour $\left.\pm 0.04\left(\mathrm{e} \mathrm{bohr}{ }^{-3}\right)^{1 / 2}\right)$.

and $\left[\mathrm{Ru}\left(=\mathrm{C}=\mathrm{CH}_{2}\right)(\mathrm{dppe}) \mathrm{Cp}^{*}\right] \mathrm{PF}_{6}\left([\mathbf{1 d}] \mathrm{PF}_{6}\right)^{25}$ were synthesised by literature methods. All other reagents were commercially available and used as received. NMR spectra were recorded in $\mathrm{CDCl}_{3}$ solutions at $23{ }^{\circ} \mathrm{C}$ on Bruker and Varian Mercury-400 $\left({ }^{1} \mathrm{H}, 399.97 \mathrm{MHz} ;{ }^{31} \mathrm{P}, 161.10 \mathrm{MHz}\right)$, Bruker Avance 600 $\left({ }^{1} \mathrm{H}, \quad 600.1 \mathrm{MHz} ;{ }^{13} \mathrm{C}, 150.9 \mathrm{MHz} ;{ }^{31} \mathrm{P}, 242.9 \mathrm{MHz}\right)$ or Varian VNMRS-700 $\left({ }^{1} \mathrm{H}, 699.73 \mathrm{MHz},{ }^{13} \mathrm{C}, 175.95 \mathrm{MHz} ;{ }^{31} \mathrm{P}\right.$, $279.89 \mathrm{MHz}$ ) spectrometers. Chemical shifts were determined relative to internal residual solvent signals $\left({ }^{1} \mathrm{H}, 7.26 \mathrm{ppm} ;{ }^{13} \mathrm{C}\right.$, $77.2 \mathrm{ppm})$ or external $\mathrm{H}_{3} \mathrm{PO}_{4}\left({ }^{31} \mathrm{P}, 0.0 \mathrm{ppm}\right)$. FT-IR spectra were measured on an Agilent Technologies Cary 660 spectrometer or a Nicolet Avatar 360 spectrometer from solutions in dichloromethane in a thin layer cell fitted with $\mathrm{CaF}_{2}$ windows. Positive and negative ion electrospray ionization (ES(+), ES(-)) mass spectra were recorded on a Waters LCT Premier XE mass spectrometer from solutions in methanol.

\section{Synthesis of $\left[\mathrm{Fe}\left\{\mathrm{C}(\mathrm{Me}) \mathrm{NH}_{2}\right\}(\mathrm{dppe}) \mathrm{Cp}\right] \mathrm{PF}_{6}[2 \mathrm{a}] \mathrm{PF}_{6}$}

The compound $\quad\left[\mathrm{Fe}\left(=\mathrm{C}=\mathrm{CH}_{2}\right)(\mathrm{dppe}) \mathrm{Cp}\right] \mathrm{PF}_{6} \quad(0.10 \quad \mathrm{~g}$, $0.14 \mathrm{mmol})$ was added to dry degassed $\mathrm{CH}_{2} \mathrm{Cl}_{2}(15 \mathrm{ml})$ in a dry, degassed Schlenk flask connected to a gas bubbler. To a separate dried, degassed flask, fitted with a Dreschel head connected to a $\mathrm{N}_{2}$ line, was added $35 \% \mathrm{NH}_{3(\mathrm{aq})}(25 \mathrm{ml})$. The output of the Dreschel head was connected by a gas-tight transfer tube in the first flask, fitted below the $\mathrm{CH}_{2} \mathrm{Cl}_{2}$ solvent level. $\mathrm{NH}_{3(\mathrm{~g})}$ was then generated by bubbling $\mathrm{N}_{2}$ gas through the $\mathrm{NH}_{3(\mathrm{aq})}$ solution, which was then subsequently bubbled through the vinylidene solution for $4 \mathrm{~h}$. The orange solution colour lightened over time. After this period, the $35 \% \mathrm{NH}_{3(1)}$ flask is removed and reaction flask flushed with $\mathrm{N}_{2}$ for at least 10 minutes to remove any excess $\mathrm{NH}_{3(\mathrm{~g})}$. The orange solution was concentrated to dryness by rotary evaporation leaving an orange residue. The orange residue was extracted with $\mathrm{CH}_{2} \mathrm{Cl}_{2}$ and filtered into vigorously stirred hexane, resulting in the instantaneous precipitation of an orange solid. The solid was collected by filtration, washed with hexane $(3 \times 10 \mathrm{ml})$ and diethyl ether $(3 \times 10 \mathrm{ml})$ then dried under vacuum $(0.079 \mathrm{~g}$, $77 \%)$. Crystals suitable for single crystal X-ray diffraction were grown from $\mathrm{CDCl}_{3} /$ pentane layer diffusion.

IR $\left(\mathrm{CH}_{2} \mathrm{Cl}_{2} / \mathrm{cm}^{-1}\right): 1651 \delta\left(\mathrm{N}-\mathrm{H}_{2}\right) .{ }^{1} \mathrm{H}$ NMR $\left(\mathrm{CDCl}_{3}, 700 \mathrm{MHz}\right)$ $\delta / \mathrm{ppm}: 1.75\left(\mathrm{~s}, 3 \mathrm{H}, \mathrm{CH}_{3}\right), 2.39-2.57\left(\mathrm{~m}, 2 \mathrm{H}, \mathrm{CH}_{2}\right.$, dppe), 2.75-2.93 (m, $2 \mathrm{H}, \mathrm{CH}_{2}$, dppe), $4.37(\mathrm{~s}, 5 \mathrm{H}, \mathrm{Cp}), 7.17(\mathrm{t}, J=7 \mathrm{~Hz}$, $4 \mathrm{H}, \mathrm{H}_{m}$, dppe), 7.30 (s, br., $\left.1 \mathrm{H}, \mathrm{NH}_{2}\right), 7.38\left(\mathrm{t}, J=7 \mathrm{~Hz}, 4 \mathrm{H}, \mathrm{H}_{m}\right.$, dppe), $7.44\left(\mathrm{t}, J=7 \mathrm{~Hz}, 2 \mathrm{H}, \mathrm{H}_{p}\right.$, dppe), 7.46-7.52 (m, 6H, $\mathrm{H}_{p}$ and $\mathrm{H}_{o}$, dppe), 7.53-7.60 (m, $4 \mathrm{H}, \mathrm{H}_{o}$, dppe), 8.17 (s, br., $1 \mathrm{H}$, $\left.\mathrm{NH}_{2}\right) .{ }^{31} \mathrm{P}\left\{{ }^{1} \mathrm{H}\right\}$ NMR ( $\left.\mathrm{CDCl}_{3}, 400 \mathrm{MHz}\right) \delta / \mathrm{ppm}: 106.9$ (s, Fe-dppe). ${ }^{13} \mathrm{C}\left\{{ }^{1} \mathrm{H}\right\}$ NMR $\left(\mathrm{CDCl}_{3}, 700 \mathrm{MHz}\right) \delta / \mathrm{ppm}: 26.8$ (t, $J=$ $23 \mathrm{~Hz}, \mathrm{CH}_{2}$, dppe), 43.2 (s, $\mathrm{CH}_{3}$ ), 83.1 (s, Cp), 128.8 (t, $J=4 \mathrm{~Hz}$, $\mathrm{C}_{m}$, dppe), 129.5 (t, $J=4 \mathrm{~Hz}, \mathrm{C}_{o}$, dppe), 130.4 (s, $\mathrm{C}_{p}$, dppe), 131.3 (s, $\mathrm{C}_{p}$, dppe), 131.8 (t, $J=4 \mathrm{~Hz}, \mathrm{C}_{m}$, dppe), 132.5 (t, $J=$ $4 \mathrm{~Hz}, \mathrm{C}_{o}$, dppe), 133.4-133.7 (m, $\mathrm{C}_{\mathrm{i}}$, dppe), 139.2-139.6 (m, $\mathrm{C}_{\mathrm{i}}$, dppe), $274.1\left(\mathrm{t}, J=22 \mathrm{~Hz}, \mathrm{C}_{\alpha}\right)$. ES (+)-MS $(\mathrm{m} / \mathrm{z}): 562\left[\mathrm{M}-\mathrm{PF}_{6}\right]^{+}$. Calculated for $\mathrm{C}_{33} \mathrm{H}_{34} \mathrm{NF}_{6} \mathrm{P}_{3} \mathrm{Fe}$ : C, 56.00; H, 4.85. Found: C, 56.12; H, 4.91 .

\section{Synthesis of $\left[\mathrm{Ru}\left\{\mathrm{C}(\mathrm{Me}) \mathrm{NH}_{2}\right\}(\mathrm{dppe}) \mathrm{Cp}\right] \mathrm{PF}_{6}[2 \mathrm{~b}] \mathrm{PF}_{6}$}

In a manner as described above, $\mathrm{NH}_{3(\mathrm{~g})}$ was bubbled through a solution of $\left[\mathrm{Ru}\left(=\mathrm{C}=\mathrm{CH}_{2}\right)(\mathrm{dppe}) \mathrm{Cp}\right] \mathrm{PF}_{6}(0.061 \mathrm{~g}, 0.082 \mathrm{mmol})$ in dry degassed $\mathrm{CH}_{2} \mathrm{Cl}_{2}(6 \mathrm{ml})$ for $4 \mathrm{~h}$. The yellow solution colour lightened over time. Work up as described above gave the product as a yellow powder $(0.049 \mathrm{~g}, 79 \%)$. Crystals suitable for single crystal X-ray diffraction were grown from $\mathrm{CH}_{2} \mathrm{Cl}_{2}$ / hexane layer diffusion.

IR $\left(\mathrm{CH}_{2} \mathrm{Cl}_{2} / \mathrm{cm}^{-1}\right): 1605 \delta\left(\mathrm{N}-\mathrm{H}_{2}\right) \cdot{ }^{1} \mathrm{H} \mathrm{NMR}\left(\mathrm{CDCl}_{3}, 400 \mathrm{MHz}\right)$

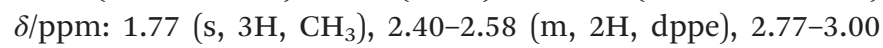
(m, 2H, dppe), 4.80 (s, 5H, Cp), 7.06 (s, br., $1 \mathrm{H}, \mathrm{NH}_{2}$ ), 7.15 
(t, $\left.J=8 \mathrm{~Hz}, 4 \mathrm{H}, \mathrm{H}_{m}, \mathrm{dppe}\right), 7.37$ (t, $J=8 \mathrm{~Hz}, 4 \mathrm{H}, \mathrm{H}_{m}$, dppe), $7.38\left(\mathrm{t}, J=8 \mathrm{~Hz}, 2 \mathrm{H}, \mathrm{H}_{p}\right.$, dppe), 7.46-7.51 (m, 6H, $\mathrm{H}_{o}$ and $\mathrm{H}_{p}$, dppe), 7.59 (t, $J=8 \mathrm{~Hz}, 4 \mathrm{H}, \mathrm{H}_{o}$, dppe), 7.89 (s, br., $1 \mathrm{H}, \mathrm{NH}_{2}$ ). ${ }^{31} \mathrm{P}\left\{{ }^{1} \mathrm{H}\right\}$ NMR $\left(\mathrm{CDCl}_{3}, 400 \mathrm{MHz}\right) \delta / \mathrm{ppm}$ : 87.9 (s, Ru-dppe). ${ }^{13} \mathrm{C}\left\{{ }^{1} \mathrm{H}\right\} \mathrm{NMR}\left(\mathrm{CDCl}_{3}, 700 \mathrm{MHz}\right) \delta / \mathrm{ppm}: 43.9\left(\mathrm{~s}, \mathrm{CH}_{3}\right), 27.0(\mathrm{t}$, $J=23 \mathrm{~Hz}, \mathrm{CH}_{2}$, dppe), 87.2 (s, Cp), 128.7 (t, $J=5 \mathrm{~Hz}, \mathrm{C}_{m}, \mathrm{dppe}$ ), 129.4 (t, $J=5 \mathrm{~Hz}, \mathrm{C}_{o}$, dppe), 130.3 (s, $\left.\mathrm{C}_{p}, \mathrm{dppe}\right), 131.1$ (t, $J=$ $5 \mathrm{~Hz}, \mathrm{C}_{m}$, dppe), 131.3 (s, $\mathrm{C}_{p}$, dppe), 132.3-132.5 (m, $\mathrm{C}_{\mathrm{i}}, \mathrm{dppe}$ ), 132.7 (t, $J=5 \mathrm{~Hz}, \mathrm{C}_{o}$, dppe), 139.7-140.1 (m, $\left.\mathrm{C}_{\mathrm{i}}\right), 256.6(\mathrm{t}, J=$ $\left.13 \mathrm{~Hz}, \mathrm{C}_{\alpha}\right)$. ES (+)-MS (m/z): $608\left[\mathrm{M}-\mathrm{PF}_{6}\right]^{+}$. ES (-)-MS $(\mathrm{m} / \mathrm{z})$ : $145\left[\mathrm{PF}_{6}\right]^{-}$. Calculated for $\mathrm{C}_{33} \mathrm{H}_{34} \mathrm{NF}_{6} \mathrm{P}_{3} \mathrm{Ru}: \mathrm{C}, 52.58 ; \mathrm{H}, 4.55$. Found: C, 52.54; H, 4.64 .

\section{Synthesis of $\left[\mathrm{Ru}\left\{\mathrm{C}(\mathrm{Me}) \mathrm{NH}_{2}\right\}\left(\mathrm{PPh}_{3}\right)_{2} \mathrm{Cp}\right] \mathrm{PF}_{6}[2 \mathrm{c}] \mathrm{PF}_{6}$}

In a manner similar to that described above, $\mathrm{NH}_{3(\mathrm{~g})}$ was bubbled through a solution of $\left[\mathrm{Ru}\left(=\mathrm{C}=\mathrm{CH}_{2}\right)\left(\mathrm{PPh}_{3}\right)_{2} \mathrm{Cp}\right] \mathrm{PF}_{6}$ $(0.10 \mathrm{~g}, 0.12 \mathrm{mmol})$ in dry degassed $\mathrm{CH}_{2} \mathrm{Cl}_{2}(6 \mathrm{ml})$ for $1 \mathrm{~h}$. The orange solution colour lightened over time. Work-up as described above gave the product as an orange powder (0.095 g, 94\%). Crystals suitable for single crystal X-ray diffraction were grown from $\mathrm{CH}_{2} \mathrm{Cl}_{2}$ /ethyl acetate layer diffusion.

IR $\left(\mathrm{CH}_{2} \mathrm{Cl}_{2} / \mathrm{cm}^{-1}\right): 1604 \delta\left(\mathrm{N}-\mathrm{H}_{2}\right) \cdot{ }^{1} \mathrm{H} \mathrm{NMR}\left(\mathrm{CDCl}_{3}, 600 \mathrm{MHz}\right)$ $\delta /$ ppm: $2.90\left(\mathrm{~s}, 3 \mathrm{H}, \mathrm{CH}_{3}\right), 4.53(\mathrm{~s}, 5 \mathrm{H}, \mathrm{Cp}), 6.96(\mathrm{~s}$, br. $1 \mathrm{H}$, $\mathrm{NH}_{2}$ ), 7.05 (t, $\left.J=8 \mathrm{~Hz}, 12 \mathrm{H}, \mathrm{H}_{o}, \mathrm{PPh}_{3}\right), 7.30(\mathrm{t}, J=8 \mathrm{~Hz}, 12 \mathrm{H}$, $\mathrm{H}_{m}, \mathrm{PPh}_{3}$ ), 7.43 (t, $J=8 \mathrm{~Hz}, 6 \mathrm{H}, \mathrm{H}_{p}, \mathrm{PPh}_{3}$ ), 8.40 (s, br., $1 \mathrm{H}$, $\left.\mathrm{NH}_{2}\right) .{ }^{31} \mathrm{P}$ NMR $\left(\mathrm{CDCl}_{3}, 400 \mathrm{MHz}\right) \delta / \mathrm{ppm}: 48.2\left(\mathrm{~s}, \mathrm{Ru}-\left(\mathrm{PPh}_{3}\right)_{2}\right)$. ${ }^{13} \mathrm{C} \mathrm{NMR}\left(\mathrm{CDCl}_{3}, 600 \mathrm{MHz}\right) \delta / \mathrm{ppm}: 44.3\left(\mathrm{~s}, \mathrm{CH}_{3}\right), 89.1$ (s, Cp), 128.7 (t, $J=5 \mathrm{~Hz}, \mathrm{C}_{m}, \mathrm{PPh}_{3}$ ), 130.5 (s, Cp, $\left.\mathrm{PPh}_{3}\right), 133.6$ (t, $J=$ $\left.5 \mathrm{~Hz}, \mathrm{C}_{o}, \mathrm{PPh}_{3}\right), 135.9-136.3\left(\mathrm{~m}, \mathrm{C}_{\mathrm{i}}, \mathrm{PPh}_{3}\right), 253.4\left(\mathrm{~m}, \mathrm{C}_{\alpha}\right) . \mathrm{ES}$ (+)-MS (m/z): $734\left[\mathrm{M}-\mathrm{PF}_{6}\right]^{+}, 472\left[\mathrm{M}-\mathrm{PPh}_{3}-\mathrm{PF}_{6}\right]^{+}$. ES (-)-MS $(\mathrm{m} / \mathrm{z}): 145\left[\mathrm{PF}_{6}\right]^{-}$. Calculated for $\mathrm{C}_{43} \mathrm{H}_{40} \mathrm{NF}_{6} \mathrm{P}_{3} \mathrm{Ru}: \mathrm{C}, 58.65$; H, 4.61. Found: C, 58.65; H, 4.61.

\section{Synthesis of $\left[\mathrm{Ru}\left\{=\mathrm{C}(\mathrm{Me}) \mathrm{NH}_{2}\right\}(\mathrm{dppe}) \mathrm{Cp}^{*}\right] \mathrm{PF}_{6}[2 \mathrm{~d}] \mathrm{PF}_{6}$}

In a manner as described above, $\mathrm{NH}_{3(\mathrm{~g})}$ was bubbled through a solution of $\left[\mathrm{Ru}\left(=\mathrm{C}=\mathrm{CH}_{2}\right)(\mathrm{dppe}) \mathrm{Cp}^{*}\right] \mathrm{PF}_{6}(0.11 \mathrm{~g}, 0.14 \mathrm{mmol})$ in dry degassed $\mathrm{CH}_{2} \mathrm{Cl}_{2}(15 \mathrm{ml})$ for $24 \mathrm{~h}$. The solution colour changed from yellow to pale green gradually over time. Work up as described above gave the product as a pale green powder $(0.090 \mathrm{~g}, 78 \%)$. Crystals suitable for single crystal X-ray diffraction were grown from $\mathrm{CDCl}_{3} /$ pentane layer diffusion.

IR $\left(\mathrm{CH}_{2} \mathrm{Cl}_{2} / \mathrm{cm}^{-1}\right): 1639 \delta\left(\mathrm{N}-\mathrm{H}_{2}\right) \cdot{ }^{1} \mathrm{H} \mathrm{NMR}\left(\mathrm{CDCl}_{3}, 700 \mathrm{MHz}\right)$ $\delta /$ ppm: 1.49 (s, 15H, Cp*), $1.60\left(\mathrm{~s}, 3 \mathrm{H}, \mathrm{CH}_{3}\right), 2.20-2.40(\mathrm{~m}, 2 \mathrm{H}$, $\mathrm{CH}_{2}$, dppe), 2.73-2.91 (m, 2H, $\mathrm{CH}_{2}$, dppe), 7.07 (t, $J=8 \mathrm{~Hz}, 4 \mathrm{H}$, $\mathrm{H}_{m}$, dppe), 7.18 (s, br., $1 \mathrm{H}, \mathrm{NH}_{2}$ ), 7.36 (t, $J=8 \mathrm{~Hz}, 4 \mathrm{H}, \mathrm{H}_{m}$, dppe), 7.43 (t, $J=8 \mathrm{~Hz}, 4 \mathrm{H}, \mathrm{H}_{p}$, dppe), 7.45-7.57 (m, 8H, $\mathrm{H}_{o}$, dppe), 8.44 (s, br, $\left.1 \mathrm{H}, \mathrm{NH}_{2}\right) \cdot{ }^{31} \mathrm{P}\left\{{ }^{1} \mathrm{H}\right\} \mathrm{NMR}\left(\mathrm{CDCl}_{3}, 400 \mathrm{MHz}\right)$ $\delta /$ ppm: 86.6 (s, Ru-dppe). ${ }^{13} \mathrm{C}\left\{{ }^{1} \mathrm{H}\right\}$ NMR $\left(\mathrm{CDCl}_{3}\right) \delta / \mathrm{ppm}: 10.5$ (s, $\mathrm{CH}_{3}, \mathrm{Cp}^{*}$ ), 28.1 ( $\mathrm{t}, J=23 \mathrm{~Hz}, \mathrm{CH}_{2}$, dppe), $41.8\left(\mathrm{~s}, \mathrm{CH}_{3}\right), 96.9$ (s, $\mathrm{Cp}^{*}$ ), 128.2 (t, $J=5 \mathrm{~Hz}, \mathrm{C}_{m}$, dppe), 129.4 (t, $J=5 \mathrm{~Hz}, \mathrm{C}_{o}$, dppe), 130.5 (s, $\mathrm{C}_{p}$, dppe), 131.3 (s, $\mathrm{C}_{p}$, dppe), 132.6 (t, $J=5 \mathrm{~Hz}, \mathrm{C}_{o}$, dppe), 132.9 (t, $J=5 \mathrm{~Hz}, \mathrm{C}_{m}$, dppe), 259.6 (t, $J=13 \mathrm{~Hz}, \mathrm{C}_{\alpha}$ ). ES (+)-MS (m/z): $678\left[\mathrm{M}-\mathrm{PF}_{6}\right]^{+}, 677\left[\mathrm{M}-\mathrm{PF}_{6}-\mathrm{H}\right]^{+}$. ES (-)-MS $(\mathrm{m} / \mathrm{z}): 145 \quad\left[\mathrm{PF}_{6}\right]^{-}$. Calculated for $\mathrm{C}_{38} \mathrm{H}_{44} \mathrm{NF}_{6} \mathrm{P}_{3} \mathrm{Ru} . \mathrm{CHCl}_{3}$ :
C, 49.72; H, 4.81. Found: C, 50.73; H, 5.14. Compound [2d] $\mathrm{PF}_{6}$ crystallises as a bis(chloroform) solvate. The analysis suggests one molecule is tenaciously retained.

\section{Crystallography}

Diffraction data were collected at $120(2) \mathrm{K}\left(100(2) \mathrm{K}\right.$ for $\left.[2 \mathbf{b}] \mathrm{PF}_{6}\right)$ on a Bruker SMART CCD 6000 diffractometer $\omega$-scan, $0.3 \%$ frame) or on an Oxford Diffraction Xcalibur diffractometer $\left([2 \mathbf{b}] \mathrm{PF}_{6}\right)$ (sealed tubes, graphite monochromators, $\lambda \mathrm{Mo}-\mathrm{K} \alpha, \lambda=$ $0.71073 \AA$ ). Following absorption corrections and solution by direct methods, the structures were refined against $F^{2}$ with full matrix least-squares using the program SHELXL ${ }^{37}$ and OLEX2. ${ }^{38}$ Non-hydrogen atoms were refined with anisotropic displacement parameters with hydrogen atoms added at calculated positions and refined by use of a riding model with isotropic displacement parameters based on those of the parent atoms. Disordered atoms in the structures $[2 \mathbf{c}] \mathrm{PF}_{6}$ and $[2 \mathbf{b}] \mathrm{PF}_{6}$ were refined in isotropic approximation with fixed site occupation factors.

\section{Crystal data}

[2a] $\mathbf{P F}_{6}$. Formula: $\mathrm{C}_{33} \mathrm{H}_{34} \mathrm{NP}_{2} \mathrm{Fe} \cdot \mathrm{PF}_{6}, \quad M=$ 707.37. Monoclinic, space group $P 2_{1} / c, a=21.8057(6), b=15.4495(4), c=$ 18.9135(5) ^, $\beta=101.4690(10)^{\circ}, V=6244.5(3) \AA^{3}, Z=8, \mu=$ $0.698 \mathrm{~mm}^{-1}, D_{\text {calc }}=1.505 \mathrm{Mg} \mathrm{m}^{-3}, 2 \theta_{\max }=60^{\circ}$. Reflections collected $=81779$, unique $=18220, R_{\text {int }}=0.0318$. Data/restraints $/$ parameters $=18220 / 0 / 811, \mathrm{GooF}=1.036$. Final $R$ indices: $R_{1}=$ $0.0302(14367>2 \sigma(I)), w R_{2}=0.0803$ (all data). $\Delta \rho_{\max , \min }=$ $0.578,-0.302$ e $\AA^{-3}$. CCDC 1063656.

[2b] $\mathbf{P F}_{6}$. Formula: $\mathrm{C}_{33} \mathrm{H}_{34} \mathrm{NP}_{2} \mathrm{Ru} \cdot \mathrm{PF}_{6}, \quad M=$ 752.59. Monoclinic, space group $P 21 / c, a=21.9074(3), b=15.4771(2), c=$ 19.0631(2) $\AA$, $\beta=99.9220(10)^{\circ}, V=6366.92(14) \AA^{3}, Z=8, \mu=$ $0.704 \mathrm{~mm}^{-1}, D_{\text {calc }}=1.570 \mathrm{Mg} \mathrm{m}^{-3}, 2 \theta_{\max }=55^{\circ}$. Reflections collected $=63$ 852, unique $=14611, R_{\text {int }}=0.0420$. Data/restraints $/$ parameters $=14611 / 0 / 809 . \mathrm{GooF}=1.043$. Final $R$ indices, $R_{1}=$ $0.0389(12339>2 \sigma(I)), \mathrm{w} R_{2}=0.0971$ (all data). $\Delta \rho_{\max , \min }=$ $3.132,-0.869$ e $\AA^{-3}$. CCDC 1063659.

[2c] $\mathrm{PF}_{6}$. Formula: $\mathrm{C}_{43} \mathrm{H}_{40} \mathrm{NP}_{2} \mathrm{Ru} \cdot \mathrm{PF}_{6}, \quad M=$ 878.74. Orthorhombic, space group $P 2_{1} 2_{1} 2_{1}, a=14.287(2), b=21.502(4), c=$ $37.246(6) \AA, V=11442(3) \AA^{3}, Z=12, \mu=0.600 \mathrm{~mm}^{-1}, D_{\text {calc }}=$ $1.530 \mathrm{Mg} \mathrm{m}^{-3}, 2 \theta_{\max }=58^{\circ}$. Reflections collected $=158766$, unique $=30397, R_{\text {int }}=0.0800$. Data $/$ restraints $/$ parameters $=$ $30397 / 66 / 1455$. GooF $=1.030$. Final $R$ indices, $R_{1}=0.0528$ $(25573>2 \sigma(I)), \mathrm{w}_{2}=0.1265$ (all data). $\Delta \rho_{\max , \min }=1.666$, -1.266 e $\AA^{-3}$. CCDC 1063657.

[2d]PF $\mathbf{P F}_{6}$. Formula: $\mathrm{C}_{38} \mathrm{H}_{44} \mathrm{NP}_{2} \mathrm{Ru} \cdot \mathrm{PF}_{6} \cdot 2 \mathrm{CHCl}_{3}, M=1061.46$. Triclinic, space group $P \overline{1}, a=10.9534(6), b=13.4096(8), c=$ 15.8099(9) ̊, $\alpha=83.8710(10), \beta=76.3000(10), \gamma=81.0140(10)^{\circ}$, $V=2222.5(2) \AA^{3}, Z=2, \mu=0.878 \mathrm{~mm}^{-1}, D_{\text {calc }}=1.586 \mathrm{Mg} \mathrm{m}^{-3}$, $2 \theta_{\max }=58^{\circ}$. Reflections collected $=43327$, unique $=11826$, $R_{\text {int }}=0.0228$. Data/restraints/parameters $=11826 / 44 / 520$. GooF $=1.077$. Final $R$ indices, $R_{1}=0.0526(10787>2 \sigma(I))$ and $\mathrm{w} R_{2}=0.1356$ (all data). $\Delta \rho_{\max , \min }=2.371,-1.956 \mathrm{e}^{-3}$. CCDC 1063658. 


\section{Computational}

All the calculations were performed with the Gaussian 09 program package, ${ }^{39}$ using the B3LYP functional, ${ }^{40}$ LANL2DZ basis set for $\mathrm{Ru}$ or $\mathrm{Fe}$, and $6-31 \mathrm{G}^{* *}$ for all other atoms. ${ }^{41} \mathrm{~A}$ conductor-like polarization continuum model CPCM of $\mathrm{CH}_{2} \mathrm{Cl}_{2}$ solvent was applied to all calculations, and results analyzed further with GaussSum. ${ }^{42}$ Structures obtained were confirmed as true minima by the absence of imaginary frequencies.

\section{Acknowledgements}

S.G.E. gratefully acknowledges funding from the University of Durham in the form of a Durham Doctoral Scholarship, and the University of Western Australia. P.J.L. holds an Australian Research Council Future Fellowship [FT120100073]. The authors acknowledge the facilities, scientific and technical assistance of the Australian Microscopy \& Microanalysis Research Facility at the Centre for Microscopy, Characterisation \& Analysis, The University of Western Australia, a facility funded by the University, State and Commonwealth Governments.

\section{References}

1 M. N. Hopkinson, C. Richter, M. Schedler and F. Glorius, Nature, 2014, 510, 485.

2 A. Igau, H. Grützmacher, A. Baceiredo and G. Bertrand, J. Am. Chem. Soc., 1988, 110, 6463.

3 M. Soleilhavoup, A. Caceiredo, O. Treutler, R. Ahlrichs, M. Nieger and G. Bertrand, J. Am. Chem. Soc., 1992, 114, 10959.

4 (a) N. Merceron, K. Miqueu, A. Baceiredo and G. Bertrand, J. Am. Chem. Soc., 2002, 124, 6806; (b) N. Merceron-Saffon, A. Baceiredo, H. Gornitzka and G. Bertrand, Science, 2003, 301, 1223.

5 L. M. Slaughter, Comments Inorg. Chem., 2008, 29, 46.

6 (a) C. A. Dyker, V. Lavallo, C. Donnadieu and G. Bertrand, Angew. Chem., Int. Ed., 2008, 47, 3206; (b) S. Klein, R. Tonner and G. Frenking, Angew. Chem., Int. Ed., 2010, 16, 10160.

7 (a) E. Despagnet, H. Gornitzka, A. B. Rozhenko, W. W. Schoeller, D. Bourissou and G. Bertrand, Angew. Chem., Int. Ed., 2002, 41, 2835; (b) E. Despagnet-Ayoub, S. Sole, H. Gortnitzka, A. B. Rozhenko, W. W. Schoeller, D. Bourissou and G. Bertrand, J. Am. Chem. Soc., 2003, 125, 124.

8 (a) V. Lavallo, J. Mafhouz, Y. Canac, B. Donnadieu, W. W. Schoeller and G. Bertrand, J. Am. Chem. Soc., 2004, 126, 8670; (b) X. Cattoën, H. Gornitzka, D. Bourissou and G. Bertrand, J. Am. Chem. Soc., 2004, 126, 1342.

9 (a) C. M. Crudden and D. P. Allen, Coord. Chem. Rev., 2004, 248, 2247; (b) O. Schuster, L. R. Yang, H. G. Raubenheimer and M. Albrecht, Chem. Rev., 2009, 109, 3445; (c) R. H. Crabtree, J. Organomet. Chem., 2005, 690, 5451; (d) P. L. Arnold and S. Pearson, Coord. Chem. Rev., 2007, 251, 596.

10 (a) D. S. Weinberger, M. Melaimi, C. E. Moore, A. L. Rheingold, G. Frenking, P. Jerabek and G. Bertrand, Angew. Chem., Int. Ed., 2013, 52, 8964; (b) D. Martin, M. Melaimi, M. Soleilhavoup and G. Bertrand, Organometallics, 2011, 30, 5304; (c) M. Melaimi, M. Soleilhavoup and G. Bertrand, Angew. Chem., Int. Ed., 2010, 49, 8810; (d) F. E. Hahn and M. C. Jahnke, Angew. Chem., Int. Ed., 2008, 47, 3122 .

11 (a) J. Vignolle, X. Cattoen and D. Bourissou, Chem. Rev., 2009, 109, 3333; (b) M. Melaimi, M. Soleilhavoup and G. Bertrand, Angew. Chem., Int. Ed., 2010, 49, 8810.

12 (a) A. S. K. Hashmi, T. Hengst, C. Lothschütz and F. Rominger, Adv. Synth. Catal., 2010, 352, 1315; (b) A. S. K. Hashmi, T. Häffner, M. Rudolph and F. Rominger, Eur. J. Org. Chem., 2011, 667; (c) M. C. Blanco Jaimes, C. R. N. Bohling, J. M. Serrano-Becerra and A. S. K. Hashmi, Angew. Chem., Int. Ed., 2013, 52, 7963.

13 (a) W. W. Schoeller, D. Eisner, S. Grigoleit, A. B. Rozhenko and A. Alijah, J. Am. Chem. Soc., 2000, 122, 10115; (b) W. W. Schoeller, A. R. Rozhenko and A. Alijah, J. Organomet. Chem., 2001, 617-618, 435; (c) W. A. Herrmann, K. Ofele, D. von Preysing and E. Herdtweck, J. Organomet. Chem., 2003, 684, 235; (d) G. D. Frey, E. Herdtwerk and W. A. Herrmann, J. Organomet. Chem., 2006, 691, 2465.

14 R. W. Alder, P. R. Allen, M. Murray and A. G. Orpen, Angew. Chem., Int. Ed. Engl., 1996, 35, 1121.

15 A. J. Arduengo III, R. L. Harlow and M. Kline, J. Am. Chem. Soc., 1991, 113, 361.

16 A. J. Arduengo III, J. R. Goerlich and W. J. Marshall, J. Am. Chem. Soc., 1995, 117, 11027.

17 E. O. Fischer and A. Maasböl, Angew. Chem., Int. Ed. Engl., 1964, 3, 580 .

18 (a) M. A. Schwindt, J. R. Miller and L. S. Hegedus, J. Organomet. Chem., 1991, 413, 143; (b) J. M. Moretó, S. Ricart, K. H. Dötz and E. Molins, Organometallics, 2000, 20, 62; (c) R. Aumann and J. Schröder, Chem. Ber., 1990, 123, 2053; (d) C. F. Bernasconi, K. W. Kittredge and F. X. Flores, J. Am. Chem. Soc., 1999, 121, 6630; (e) G. Seidel, B. Gabor, R. Goddard, B. Heggen, W. Thiel and A. Fuerstner, Angew. Chem., Int. Ed., 2014, 53, 879; (f) M. J. Winter and S. Woodward, J. Chem. Soc., Chem. Commun., 1989, 457; $(g)$ C. F. Bernasconi and M. Ali, Organometallics, 2004, 23, 6134.

19 M. I. Bruce, Chem. Rev., 1991, 91, 197.

20 (a) H. Kopf, B. Holzberger, C. Pietraszuk, E. Hübner and N. Burzlaff, Organometallics, 2008, 27, 5894; (b) C. Bianchini, D. Masi, A. Romerosa, F. Zanobini and M. Peruzzini, Organometallics, 1999, 18, 2376; (c) H. Fischer, G. Roth, D. Reindl and C. Troll, J. Organomet. Chem., 1993, 454, 133; (d) M. Serrano-Ruiz, C. Lidrissi, S. Manas, M. Peruzzini and A. Romerosa, J. Organomet. Chem., 2014, 751, 654; (e) I. Hyder, M. Jinenez-Tenorio, M. C. Puerta and P. Valerga, Organometallics, 2011, 30, 726; (f) G. Consiglio, F. Morandini, G. F. Ciani and A. Sironi, Organometallics, 1986, 5, 1976. 
21 J. M. Lynam, Chem. - Eur. J., 2010, 16, 8238.

22 M. I. Bruce and R. C. Wallis, Aust. J. Chem., 1979, 32, 1471.

23 M. I. Bruce, C. Hameister, A. G. Swincer and R. C. Wallis, Inorg. Synth., 1982, 21, 78.

24 M. I. Bruce and A. G. Swincer, Aust. J. Chem., 1980, 33, 1471.

25 M. I. Bruce, B. G. Ellis, P. J. Low, B. W. Skelton and A. H. White, Organometallics, 2003, 22, 3184.

26 M. I. Bruce, K. Costuas, B. G. Ellis, J.-F. Halet, P. J. Low, B. Moubaraki, K. S. Murray, N. Ouddaï, G. J. Perkins, B. W. Skelton and A. H. White, Organometallics, 2007, 26, 3735.

27 M. I. Bruce and G. A. Koutsantonis, Aust. J. Chem., 1991, 44, 207.

28 M. P. Gamasa, J. Gimeno, B. M. Martìn-Vaca, J. Borge, S. García-Granda and E. Perez-Carreño, Organometallics, 1994, 13, 4045.

29 A. G. Alonso and L. B. Reventós, J. Organomet. Chem., 1988, 338, 249.

30 K. Y. Ghebreyessus and J. H. Nelson, Inorg. Chim. Acta, 2003, 350, 12.

31 D. Duraczynska and J. H. Nelson, Dalton Trans., 2003, 449.

32 H. D. Hansen and J. H. Nelson, Organometallics, 2000, 19, 4740.

33 R. L. Cordiner, D. Albesa-Jove, R. L. Roberts, J. D. Farmer, H. Puschmann, D. Corcoran, A. E. Goeta, J. A. K. Howard and P. J. Low, J. Organomet. Chem., 2005, 690, 4908.

34 G. Argouarch, P. Thominot, F. Paul, L. Toupet and C. Lapinte, C. R. Chim., 2003, 6, 209.

35 Y. Kawata and M. Sato, Organometallics, 1997, 16, 1093.

36 J. H. Bowie, M. I. Bruce, M. A. Buntine, A. S. Gentleman, D. C. Graham, P. J. Low, G. F. Metha, C. Mitchell,
C. R. Parker, B. W. Skelton and A. H. White, Organometallics, 2012, 31, 5262.

37 G. M. Sheldrick, Acta Crystallogr., Sect. A: Fundam. Crystallogr., 2008, 64, 112.

38 O. V. Dolomanov, L. J. Bourhis, R. J. Gildea, J. A. K. Howard and H. Puschmann, J. Appl. Crystallogr., 2009, 42, 339-341.

39 M. J. Frisch, G. W. Trucks, H. B. Schlegel, G. E. Scuseria, M. A. Robb, J. R. Cheeseman, G. Scalmani, V. Barone, B. Mennucci, G. A. Petersson, H. Nakatsuji, M. Caricato, X. Li, H. P. Hratchian, A. F. Izmaylov, J. Bloino, G. Zheng, J. L. Sonnenberg, M. Hada, M. Ehara, K. Toyota, R. Fukuda, J. Hasegawa, M. Ishida, T. Nakajima, Y. Honda, O. Kitao, H. Nakai, T. Vreven, J. A. Montgomery Jr., J. E. Peralta, F. Ogliaro, M. Bearpark, J. J. Heyd, E. Brothers, K. N. Kudin, V. N. Staroverov, R. Kobayashi, J. Normand, K. Raghavachari, A. Rendell, J. C. Burant, S. S. Iyengar, J. Tomasi, M. Cossi, N. Rega, J. M. Millam, M. Klene, J. E. Knox, J. B. Cross, V. Bakken, C. Adamo, J. Jaramillo, R. Gomperts, R. E. Stratmann, O. Yazyev, A. J. Austin, R. Cammi, C. Pomelli, J. W. Ochterski, R. L. Martin, K. Morokuma, V. G. Zakrzewski, G. A. Voth, P. Salvador, J. J. Dannenberg, S. Dapprich, A. D. Daniels, Ö. Farkas, J. B. Foresman, J. V. Ortiz, J. Cioslowski and D. J. Fox, Gaussian 09, Gaussian, Inc., Wallingford CT, 2009.

40 (a) A. D. Becke, J. Chem. Phys., 1993, 98, 5648; (b) P. J. Stephens, C. F. Devlin, C. F. Chabalowski and M. J. Frisch, J. Phys. Chem., 1994, 98, 11623.

41 (a) P. J. Hay and W. R. Wadt, J. Chem. Phys., 1985, 82, 299; (b) G. A. Petersson and M. A. Al-Laham, J. Chem. Phys., 1991, 94, 6081.

42 N. M. O’Boyle, A. L. Tenderholt and K. M. Langner, J. Comput. Chem., 2008, 29, 839. 